\title{
Employment Sustainability and Prospects of the Automotive Industry in Saudi Arabia
}

\author{
By Nadia Yusuf ${ }^{*}$, Vivian Nasrulddin ${ }^{1}$
}

\begin{abstract}
The research revolves around the automotive industry of Saudi Arabia and how the industry can be used as an opportunity towards creating more employment opportunities for the youth. A detailed discussion has been done to identify the existing problems in the concerned sector along with a brief background study. The employment opportunities and related trade conditions are also discussed. The growth prospects of the automotive industry along with the investment opportunities have been provided. In the later part of the research, recommendations for overall industry growth are mentioned. The report also contains references from reputed authors and trusted sources, which makes the report more authentic and informative. Detailed evaluation of the obtained data shows that changes in import and export rates can influence the employment market in terms of generating trade volume. Moreover, attempt to attract foreign investment through encouraging trade transactions can result in strengthening industrial growth through creating better employment opportunities.
\end{abstract}

Keywords: Automotive industry, Saudi Arabia, automobile manufacturing, technological advancements, investment opportunities, trade indicators, unemployment Rate

\section{Introduction}

\subsection{Background}

Automotive industry can be termed as one of the key contributors towards the economic development of a country. As stated by Iansiti and Lakhani (2017), automotive industry growth can be used as a beneficial factor towards a collective economical future. In this report, the selected country for the research purpose is Saudi Arabia. In the Middle Eastern region, Saudi Arabia contributes the most in automotive sales. The country recorded a constant growth in the overall motor vehicles sales since 2011 (Shafie and Mahmud, 2020). The automobile industry can be associated with the national economy as the industry has a significant impact on the overall economic operations.

Saudi Arabia excels in both import and export factors of automobile sales. The industry is stated as capital intensive and like most countries; Saudi Arabia also exports a large share of the production. It has been found that the luxury cars market is also showing positive signs of growth in the segment. The Saudi Arabian government is trying to use these potential growth factors towards local operations which will be viable for job opportunities for the locals. However, there is not much light vehicle production in the country at this time. There was a significant drop observed in the unit sales after 2017. This was caused by the uncertain market conditions along with the tight liquidity of the market. After a constant decline of three years, the automotive industry condition is starting to improve 
slowly. This can result in jobs for the local residents. However, for that to happen, the companies need to set up local operations first. The tourism industry can also be associated with this scenario as tourists act as a source of demand in the automobile industry.

\subsection{Problem Identification}

Saudi Arabia is one of the richest countries across the globe and it is also the largest auto parts manufacturer in the Middle East. The country accounts for almost half of the vehicles sold in that region. However, there are problems present in the automobile sector as it recorded double digit drops in previous years (Tausif and haque, 2019). The automobile market worldwide suffered multiple setbacks due to the economic collapse in 2008, and the Saudi Arabian automobile industry is also among those. It can be stated that the automobile industry needs to undergo some serious modifications to create job opportunities for the youth of the country.

In this regard, the government is trying to establish a local chain of operations by the renowned global vehicle manufacturers. By doing so, job opportunities along with the expansion of technological advances can also be achieved. Luxury vehicles, SUVs or offroad vehicles are in demand due to the harsh environmental condition of the country (Azam, 2017). Various country specific regulations can also be stated as a problem for the growth of the industry. The industrial standards of Saudi Arabia are numerous and act as market barriers for new entries in the segment.

However, big names in the global automotive manufacturing sector such as Toyota or Hyundai hold a significant amount of market share in Saudi Arabia. Along with that, Mercedes and Volvo have also set up production in the region (Brown, 2019). By setting up more local chain of operations, a greater number of jobs can be ensured for the youth. Along with that, the global oil price is expected to rise with time, and this has the potential to increase sales in the country. Saudi Arabian automotive industry is import driven and due to that, local workforce can be employed in the production or manufacturing segment.

\section{Study Scope and Objectives}

\subsection{Research Questions}

- What is the present condition of the Saudi Arabian automobile industry?

- What are the chances of growth in the automotive sector of Saudi Arabia?

- Will the unemployment rate of the country somehow influence the automobile manufacturing industry?

- Whether the market rates will influence the production of automotive manufacturing industry?

- How more employment opportunities can be created in the region?

\subsection{Research Objectives}

- To find the present condition of the Saudi Arabian automotive industry.

- To find the chances of growth in Saudi Arabian automotive sector.

- To find the impact of the rate of unemployment on the automobile manufacturing industry.

- To find the influence of market rates on the automotive manufacturing industry. 
- To find ways for creating prospective employment opportunities in the region.

\subsection{Significance of Study}

The study will provide valuable insight towards the present automotive market scenarios of Saudi Arabia. Along with that, the various economic factors associated with it will also be discussed in the research. Market conditions will also be discussed to understand the growth opportunities for the automotive market. Economic changes or factors that can impact the overall manufacturing or production is also discussed here. As the focal theme of the research suggests, unemployment problems in Saudi Arabia and how that can be mitigated through creating job opportunities is mentioned as well. The relationship between the mentioned scenarios is also described as a part of the process.

\subsection{Limitation}

The research area is huge due to the size of the industry. Along with that, the re-search is done from a country perspective which makes the number of concerned organizations even higher. There are certain gaps in data as the research is conducted in a short span of time. Along with that, there are numerous manufacturers present in the automotive industry of Saudi Arabia and it was not possible to collect data from each of the manufacturers. Along with it, the lack of primary research data is also a limitation here as no interview has been done with any experienced personnel in the field.

\section{Literature Review}

The automotive industry can be stated as one of the major economic forces across the globe. Millions of transport vehicles are made by this industry and along with that, this industry consumes a huge portion of the oil supply worldwide. With time, technological advancements implemented a significant form of growth into the automotive sector (Brenner and Herrmann, 2018). With this growth, the number of employments also increased rapidly. Due to the connection with the supplier industries, the automobile industry holds a significant role in the overall economic development of a country.

The Saudi Arabian automotive industry is showing positive signs for growth. The recession caused by pandemic significantly impacted the industry, however, sales are in-creasing in recent times. The government is trying to emphasize on this growth as a way to create more job opportunities for the youth of Saudi Arabia (Jadoon et al. 2020). Achieving this purpose successfully requires to form ties with the global manufacturers in the concerned industry, so that more employment opportunities are created through local operations.

\subsection{Employment Opportunity and Trade Conditions Supporting Economic Growth}

The Saudi Arabian automotive sector is also associated with the vehicle market of the Gulf cooperation council area. This region has shown steady growth in the previous year's along with market expansion (Mirza, 2021). As of 2020, more than half of the overall GDP of the country is accumulated from foreign trade. The Saudi Arabia free market has gone through a set of changes in quick succession. Due to that, the overall condition has im-proved and gave the country the recognition as a global power having the latest infrastructure. 
The trade conditions are getting better as the government is implementing economic development plans towards achieving long term economics goals. The overall plan for trade benefits can be stated as the creation of a local automotive industry (Saudi embassy, 2021). However, the specific standards provided by the Saudi Arabian government are considered problematic for any kind of export coming in from the U.S (Trade.gov, 2019). These standards also include various requirements for the import segment which can result in a lot of paperwork. Along with it, the inclusion of the five percent VAT three years ago has also resulted in roadblocks for the overall trade scenarios (Park, 2018). The Saudi Arabia Standards Organization has also mentioned that any trade related to engine or transmission parts should follow a specific set of standards. These complexes set of standards can force the companies to create or establish a local chain of networks for the production purposes (Mahmood, 2017). Having more local production units will also create more opportunities for the local people and the youth of the country. In this regard, the government can also implement rules that ensure that the company employs more local people in their manufacturing units.

\subsection{Automobile Industry Growth Prospects}

There are numerous prospects of growth in the Saudi Arabian automotive sector. The recent increase in the fuels did not create any significant impact on the overall industry. Along with that, the government is also supporting the growth of SUV production. The SUVs are one of the largest selling vehicles in Saudi Arabia along with the luxury vehicles and the government is working on legislation policies for both segments. Along with that, there are plans in progress which focuses on the production of the fuel-efficient vehicles such as the sedan. Before 2018, driving was prohibited for the women of Saudi Arabia. However, that law was abolished after 2018 which can be stated as a historic moment for the women of the country (Specia, 2019). This has created new prospects of sales into the market as the number of customers is not limited to men anymore. The inclusion of more than two thousand female drivers significantly boosted demand.

The market condition is prospective and can be stated as beneficial in long run scenarios. Along with it, the high revenue stream will cause more demands for newer vehicles in the segment. The market has shown positive growth in the beginning of 2020 and there is an expected sale of almost 2 million cars over the years (Mirza, 2021). However, the industry observed a sales drop of $70 \%$ in April due to the pandemic and the lockdown imposed by it. Like any other industry the automotive sector also took a hit and great losses were recorded. The government implemented a special value added tax over the car values, which resulted in more than $100 \%$ increase in overall sales in the following months. Before the pandemic, the overall aftermarket sales of the Saudi Arabian region were expected to reach 50 million USD, which is still considered as an achievable target.

\subsection{Trade Volume and Trade Balance}

As per the trade scenario, Saudi Arabia is one of the largest goods exporters and also one of the largest import markets across the globe. More than half of the overall GDP of the country is represented by the foreign trade. The greater parts of these exports are represented by petroleum products and these sectors have observed growth compared to the previous years (Belloumi and Alshehry, 2020). The other portion of the trade consists 
of petroleum products such as propylene. The overall value that these products hold in the segment is around $14 \%$ of the total value. The largest share of the Saudi Arabian imports is in the form of machinery and electrical instruments. The automotive industry comes third in the overall segment.

The overall after market trade and sales value of the automotive market stands at almost 73 million units and the estimated value is 28 billion USD (Mirza, 2020). However, the export values are expected to drop in the later part of 2020 along with the imports. This has occurred due to the pandemic scenarios that have severely impacted the overall dynamics related to global trade. Saudi Arabia trade partners are among some of the largest economies of the world such as India, China and Japan. The country also has several import ties with the United States, Germany and Japan. This large number of associations with multiple countries has resulted in numerous trade sequences for the country. Along with that, the government has also established economic cities with the purpose of attracting inter-national trade. However, the overall trade balance of the country fluctuates regularly as it depends a lot on the international market rate of oil. The overall trade surplus was reduced to 129 billion USD due to the market fluctuations on a global scale (trade.gov. 2019). In 2020, the surplus rate is at a record high as the pandemic caused massive drop in the oil prices.

\subsection{Investment Opportunities and Trade Indicators}

As a growing economy consisting of market liberalization benefits, the Saudi Arabi-an investment sector is full of multiple prospects. These can also be used as a new source of market entry along with creating business profiles that are viable for growth in long term scenarios (Ali et al. 2019). The growing private sector of the country also ensures that there are multiple presences of diverse opportunities in various stock shares (Jawadi et al. 2018). The country is also diversifying its economy towards various sectors.

The investment opportunities are plenty in the automotive sector as the industrial sector is also associated with it. As the government is looking for more centralized operations by the global manufacturers, there will be a greater number of production units in this segment. Significant amounts of investments can be implemented towards the global manufacturers that hold the largest amount of market share in the industry. Welldeveloped infrastructure and the efficient logistics network also make it more viable for any incoming investments.

\subsection{Gap in Research}

There are a couple scenarios where the research fails to deliver adequate data. According to the statement of Shams and Thrassou (2019), there can be certain gaps present in an industry analysis on academic scale. In case of this research, the lack of primary data can be stated as a research gap. Factors such as the pre-sent market condition or the region-specific unemployment rate cannot be obtained due to the lack of direct communication. Along with that, the research has been conducted in a short period of time. A research of this scale needs more time to include all the concerned factors or scenarios. Factors such as the purchasing manager's index or overall inflation rate are also not considered here.

The automotive industry of Saudi Arabia suffered significant losses in the past. This was 
caused due to the strict government policies and regulations. However, the industry is showing signs of growth as it is slowly turning around from the previous losses. The government is trying to establish centralized operations which can create more job opportunities for the youth. As a trade-based country, chances of investment in the automotive sector of Saudi Arabia is also high as the manufacturers are observing an upward trend in the overall market scenarios.

\section{Methodology}

Determining an appropriate research method expands chances to follow a systematic approach for testing the relationship between the identified research variables. This part of the study concentrates on discussing the importance of assessing quantitative data for designing operational variable through collecting relevant data. Moreover, analysis of theoretical framework is also important to consider in this section for addressing the re-search questions and comment on importance of automotive industry in creating employment opportunity in Saudi Arabia. Besides, this segment has emphasized on expressing the importance of secondary data to comment on role of automotive industry in aforementioned country to create employment opportunities.

\subsection{Theoretical Framework}

To comment on the role of automobile sector in creating better employment opportunities and supporting the economic growth of Saudi Arabia, the following theoretical framework can be considered.

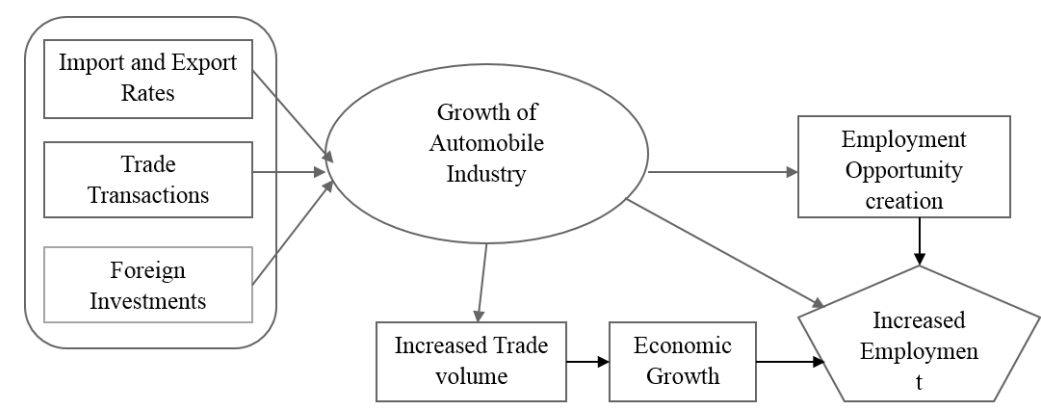

Figure 1: Theoretical Framework

As indicated in the figure 1, emphasis on boosting the growth of automotive industry has been supportive for improving the employment market. Here, evaluating the import and export rates along with global trade transaction can influence the growth of automotive manufactures in terms of strengthening the economic background. Moreover, increase in foreign direct investment strengthening global trade transactions can be effective to support the overall growth of business ensuring the increased level of job creation (FragaLamas and Fernández-Caramés, 2019). In addition, job creation or employment market of a country being dependent on the youth population and economic stability of a country, emphasis of the respective government on supporting the growth of automotive sector can result in creating more employment opportunity. This, in turn, can lead to increase the 
employment rate through establishing automobile manufacturing factories. Now considering these, research hypothesis has been developed in the next section to carry out a systematic research.

\subsection{Hypothesis}

Considering the research objectives, the following hypotheses are to be tested to address the research questions and comment on the impact of automotive industry on creating employment opportunities in Saudi Arabia.

H1: Increasing export rate of Saudi Arabia from automotive sector can hold statistically significant impact on controlling trade volume for creating better employment opportunities.

H2: Increasing import rate of Saudi Arabia from automotive sector can hold statistically significant impact on controlling trade volume for creating better employment opportunities.

H3: Evaluating total trade balance of Saudi Arabia can hold statistically significant impact on controlling employment rate to create better employment opportunities.

H4: Automobile sector in Saudi Arabia holds statistically significant impact on boosting the trade volume for reducing unemployment rate in this country.

\subsection{Operational Definition of Variables}

In order to proceed with this study, the dependent variable is the employment opportunity while the independent variable is the growth perspective of automobile industry in Saudi Arabia. Here, evaluation of the relationship between these dependent and independent variables can be measured through considering the following operational variables (table 1).

Table 1: Definition of Operational Variables

\begin{tabular}{|c|c|c|}
\hline \multirow[t]{4}{*}{$\begin{array}{l}\text { Independent } \\
\text { Variable }\end{array}$} & Import Rate & $\begin{array}{l}\text { Tax that is collected by the custom authorities of a country } \\
\text { for purchasing products or services from any foreign } \\
\text { country. }\end{array}$ \\
\hline & Export Rate & $\begin{array}{l}\text { Tax acquired from businesses to sell products or services to } \\
\text { other countries or foreign countries. }\end{array}$ \\
\hline & Trade Volume & $\begin{array}{l}\text { Total quantity of shares traded for specified security over a } \\
\text { particular period, which is calculated through summing up } \\
\text { import and export rates. }\end{array}$ \\
\hline & Trade Balance & $\begin{array}{l}\text { Commercial balance that reflects net export calculated after } \\
\text { subtracting import from total export over a certain period of } \\
\text { time. }\end{array}$ \\
\hline $\begin{array}{l}\text { Dependent } \\
\text { Variable }\end{array}$ & $\begin{array}{l}\text { Employment and } \\
\text { Unemployment } \\
\text { Rate }\end{array}$ & $\begin{array}{l}\text { Unemployment rate indicates the rate of employable } \\
\text { individuals who are actively seeking jobs but not able to find } \\
\text { one. This also refers to the labour resources that are } \\
\text { available to work. On the other hand, employment rate } \\
\text { signifies the percentage of people in the work force } \\
\text { supporting the overall growth of economy. Both the } \\
\text { employment and unemployment rates can be essential to } \\
\text { comment on the employment opportunity of a country. }\end{array}$ \\
\hline
\end{tabular}




\subsection{Data Collection}

The study has followed a secondary method for collecting evidence from government websites and industry publications for evaluating employment opportunity in Saudi Arabia through recording import and export rates along with trade volume and trade balance. As mentioned by Bell et al. (2018), emphasis on collecting secondary data enables chances to incur data from credible published sources providing information backed up with relevant evidence. In addition, secondary data has been collected from reliable web sources for recording statistical evidence for the past 10 years. Here, observations have been collected for commenting on the employment opportunities in Saudi Arabia through obtaining export and import rates from 2011 to 2020. Thus, the obtained data set for carrying out this study can be presented as in table 2 .

Table 2: Raw Research Data

\begin{tabular}{|c|c|c|c|c|c|c|}
\hline $\begin{array}{c}\text { Saudi } \\
\text { Arabia }\end{array}$ & \multicolumn{5}{|c|}{ Independent } & \multicolumn{2}{c|}{ Dependent } \\
\hline Years & $\begin{array}{c}\text { Export } \\
\text { (USD } \\
\text { million) }\end{array}$ & $\begin{array}{c}\text { Import } \\
\text { (USD } \\
\text { million) }\end{array}$ & $\begin{array}{c}\text { Trade } \\
\text { Balance } \\
\text { (USD } \\
\text { million) }\end{array}$ & $\begin{array}{c}\text { Trade } \\
\text { Volume } \\
\text { (USD } \\
\text { million) }\end{array}$ & $\begin{array}{c}\text { Employment } \\
\text { Rate (\% of total } \\
\text { employment) }\end{array}$ & $\begin{array}{c}\text { Unemployment } \\
\text { Rate (\% of total } \\
\text { labour force) }\end{array}$ \\
\hline 2011 & 364,139 & 127,962 & 236,177 & 492,101 & 22.07 & 5.77 \\
\hline 2012 & 387,373 & 151,260 & 236,113 & 538,633 & 22.90 & 5.52 \\
\hline 2013 & 375,360 & 163,013 & 212,347 & 538,373 & 23.76 & 5.57 \\
\hline 2014 & 341,947 & 168,239 & 173,708 & 510,186 & 23.03 & 5.72 \\
\hline 2015 & 201,491 & 163,820 & 37,671 & 365,311 & 22.73 & 5.59 \\
\hline 2016 & 183,604 & 140,169 & 43,435 & 323,773 & 24.49 & 5.65 \\
\hline 2017 & 221,835 & 134,519 & 87,316 & 356,354 & 24.26 & 6.04 \\
\hline 2018 & 294,536 & 135,211 & 159,325 & 429,747 & 24.79 & 5.93 \\
\hline 2019 & 251,800 & 144,334 & 107,466 & 396,134 & 24.68 & 5.86 \\
\hline 2020 & 155,000 & 111,000 & 44,000 & 266,000 & 24.79 & \\
\hline \multicolumn{7}{|c|}{} \\
\hline Note & Trade Volume = Export + Import \\
\hline & Trade Balance = Export - Import \\
\hline
\end{tabular}

Now, following the data set in table 2, employment opportunities in Saudi Arabia due to improving performance of automotive manufacturing industry can be evaluated. In this context, recording the trade transactions in form of import and export rates in auto-motive sector in this country can expand chances to identify future market growth opportunities. This, as a result, can be beneficial to locate the changes in employment or labor market for boosting the industrial development. Moreover, tracking the constant changes in trade volume and trade balance can help to comment on the contribution of automotive sector in creating job opportunities to support holistic economic growth.

\section{Result and Discussion}

This study emphasizes on exploring the employment opportunities in competitive market through evaluating the contribution of automobile industry in Saudi Arabia. Thus, 
a secondary research method has been applied here and following that, this segment concentrates on presenting and evaluating the obtained data for testing the research hypotheses. Here, the use of MS-Excel has been considered for collecting and analyzing the data presenting changing import and export rates for boosting the growth of automobile sector for creating better employment opportunities. Here, the relationships between the identified dependent and independent variables are also to be tested through performing correlation and multiple regression analysis in this section of the paper for commenting on role of automotive industry growth perspectives in job creation.

\subsection{Data Findings and Analysis}

In order to develop better idea on the research context and evaluate the contribution of automobile industry growth perspectives in creating better employment market and job opportunities, correlation and multiple regression tests have been performed.

\subsubsection{Correlation Analysis}

Here, three sets of correlation analysis have been performed in this task for addressing the research questions.

Table 3: 1st Set of Correlation.

\begin{tabular}{|l|c|c|}
\hline & Export (USD million) & Trade Volume (USD million) \\
\hline Export (USD million) & 1 & \\
\hline Trade Volume (USD million) & 0.985470259 & 1 \\
\hline
\end{tabular}

Following the table 3, the correlation between export rate and trade volume needs to be analyzed for commenting on the role of automotive industry in Saudi Arabia to create employment opportunities. Here, the dependent variable is trade volume while the independent variable is export rates. In this case, statistical data on performance of automotive industry for the past 10 years have been considered making the $\mathrm{N}$-value to be 10. Moreover, 95\% confidence interval level has been considered here $(\alpha=0.05)$. Now, the table 4.2.1.1 shows that correlations coefficient is $0.985(\mathrm{r}=0.985)$ and the $\mathrm{p}$-value is $0.000(p=0.000)$. Thus, the correlation coefficient number being a positive number indicates a positive relationship between the identified variables. This implies that changes in export rates holds positive and significant impact on trade volume indicating growth opportunity of automotive sector supporting labor market development in Saudi Arabia. In this context, the export rate of automotive vehicles decreasing in a significant manner up to US $\$ 155,000$ million in 2020 indicates towards the depreciation of national economy (Ceicdata.com, 2019).

Table 4: 2nd Set of Correlation.

\begin{tabular}{|l|c|c|}
\hline & Import (USD million) & Trade Volume (USD million) \\
\hline Import (USD million) & 1 & 1 \\
\hline Trade Volume (USD million) & 0.435779676 & \\
\hline
\end{tabular}

In case of this second correlation test, trade volume has been considered as the de-pendent 
variable while import rate has been counted as independent variable. As noted in the Pearson's correlation table 4, the correlation coefficient is $0.436(\mathrm{r}=0.436)$ and this value is a positive number signifies a positive relationship between the identified variables. Moreover, the correlation coefficient number being small refers that although there is positive relationship between the variables, the variables share a weakly positive relationship between the variables. This highlights that increase in import rate can help to boost trade volume, which, as a result, can strengthen economic growth of a country through attracting the attention of foreign investors. Considering the case of Saudi Arabia, a million vehicles have been imported, which include commercial vehicles and passenger cars (Trade.gov, 2019). However, as a result of economic vulnerabilities in recent years, sales of new vehicles had been reported to slump down by more than $20 \%$ in 2017 (Trade.gov, 2019).

\section{Table 5: 3rd Set of Correlation}

\begin{tabular}{|l|c|c|}
\hline & $\begin{array}{c}\text { Trade Balance } \\
\text { (USD million) }\end{array}$ & $\begin{array}{c}\text { Employment Rate } \\
\text { (\% of total employment) }\end{array}$ \\
\hline Trade Balance (USD million) & 1 & 1 \\
\hline Employment Rate (\% of total employment) & -0.516431847 & 1 \\
\hline
\end{tabular}

As indicated in the table 5, employment rate is dependent variable while the trade balance has been considered as the independent variable. Here, the correlation coefficient value being -0.517 indicates that there is a negative relationship between the chosen variables. In addition, this relationship being neither too strong nor weak shows that trade balance negatively influences employment rate as it calculates the commercial balance through subtracting import from total exports. Therefore, it can be mentioned that employment rate is not likely to be influenced by trade balance of a country (Esmail, 2018). Moreover, it is also evident that there are other variables influencing employment rate of the country and creating job opportunities through encouraging the growth of automobile industry.

\subsubsection{Multiple Linear Regressions}

The ability of a country to support the growth of trade transactions and import and export activities can be supportive to boost economic growth in terms of creating better employment opportunities. Now, considering the research context, the growth of automobile sector depends on the increasing exchange of goods and services attracting the foreign investments. Here, a multiple regression analysis has been performed to comment on the relationship between the research variables and test the hypothesis for meeting research questions.

Table 6: Model Summary

\begin{tabular}{|l|c|}
\hline Regression & \\
\hline Multiple R & 0.597999589 \\
\hline R Square & 0.357603508 \\
\hline Adjusted R Square & 0.031204511 \\
\hline Standard Error & 0.90556101 \\
\hline Observations & 10 \\
\hline
\end{tabular}


Here, intention to test the relationship between the research variables, employability rate has been considered as the dependent variable where import rate, trade balance and trade volume have been considered as the required independent variables for meeting the research questions. In this case, the number of observations is 10 as data collected from the past 10 years has been included in this study $(\mathrm{N}=10)$. Now, as shown in the table 6, the value of $\mathrm{R}$ represents the correlation between the identified variables, which has been measured at $0.358(\mathrm{R}=0.358)$. On the other hand, value of multiple $\mathrm{R} 2$ signifies the level of variation in dependent variable (employment rate), which can be regressed by the independent variables. Here, this multiple R2 value being measured at 0.598 implying that only $59.8 \%$ data can be regressed or explained, and this is a small number.

Depending on this, the ANOVA, table 7 helps to predict the suitability of regression equation to fit the obtained data set.

Table 7: ANOVA Table

\begin{tabular}{|l|c|c|c|c|c|}
\hline \multicolumn{7}{|c|}{ ANNOVA } \\
\hline & $\boldsymbol{d f}$ & $\boldsymbol{S S}$ & $\boldsymbol{M S}$ & $\boldsymbol{F}$ & Significance $\boldsymbol{F}$ \\
\hline Regression & 3 & 3.1954504 & 1.59773 & 1.948348559 & 0.223215876 \\
\hline Residual & 7 & 5.7402852 & 0.82004 & & \\
\hline Total & 10 & 8.9357356 & & & \\
\hline
\end{tabular}

Now, as indicated in the table 7, the value presented under the 'Significance F' column under 'Regression' row is 0.22 , which is greater than $0.05(0.22>0.05)$. This signifies that the regression model is unable to predict the outcome variable negating the chances of the model statistically significantly to be a perfect for the obtained data to predict the outcome variable.

Table 8: Correlation Coefficient Analysis

\begin{tabular}{|l|c|c|c|c|}
\hline & Coefficients & Standard Error & $\boldsymbol{t}$ Stat & $\boldsymbol{P}$-value \\
\hline Intercept & 26.95888237 & 2.429802078 & 11.0951 & $1.07421 \mathrm{E}-05$ \\
\hline Export (USD million) & $-5.48164 \mathrm{E}-06$ & $3.88822 \mathrm{E}-06$ & -1.4098 & 0.201444429 \\
\hline Import (USD million) & $-1.17107 \mathrm{E}-05$ & $1.86105 \mathrm{E}-05$ & -0.6293 & 0.549162244 \\
\hline
\end{tabular}

Apart from this, depending on the correlation coefficient analysis indicated in the table 8, the $p$-value presented under the export row is $0.201(p=0.201)$ and this value being greater than 0.05 indicates that there is no statistically significant relationship be-tween the identified variables. Thus, it can be interpreted that apart from import export rate generated by the automobile industry in Saudi Arabia, there are other factors that can create employment opportunity in this country. Moreover, based on this, the regression equation can be developed as

Employment rate $=-26.959+(-5.48164 \mathrm{E}-06)[$ Export $]+(-1.17107 \mathrm{E}-05)$ [Import]

Considering, this regression equation there being no statistically significant relationship between the identified independent and dependent variables, employment rate in Saudi Arabia cannot be single-handedly dealt with the import and export rates in this country. Now, in case of commenting on the growth of automobile industry in the afore-mentioned country for boosting employment growth, focus on shaping investment policies and trade 
activities can help to improve overall economic condition.

\section{Export (USD million) Residual Plot}

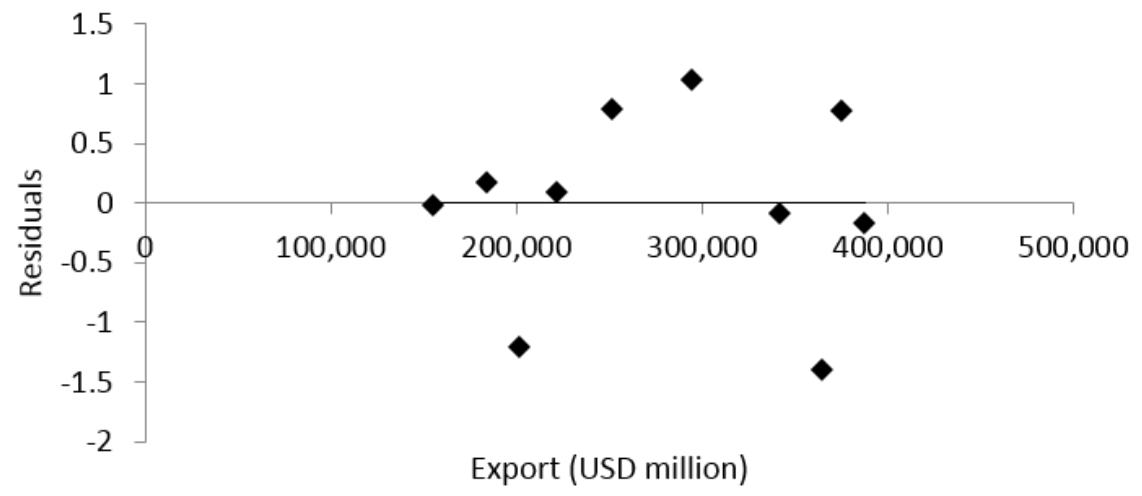

Figure 2: Residual Plot for Export Rate

As indicated in the figure 2, the data points obtained for representing the export rate in industrial activities in Saudi Arabia are scattered across the residual plot. This, as a result, notifies that the constant changes in export rates can influence the employment rates in terms of boosting the development of automotive sector in this country.

\section{Import (USD million) Residual Plot}

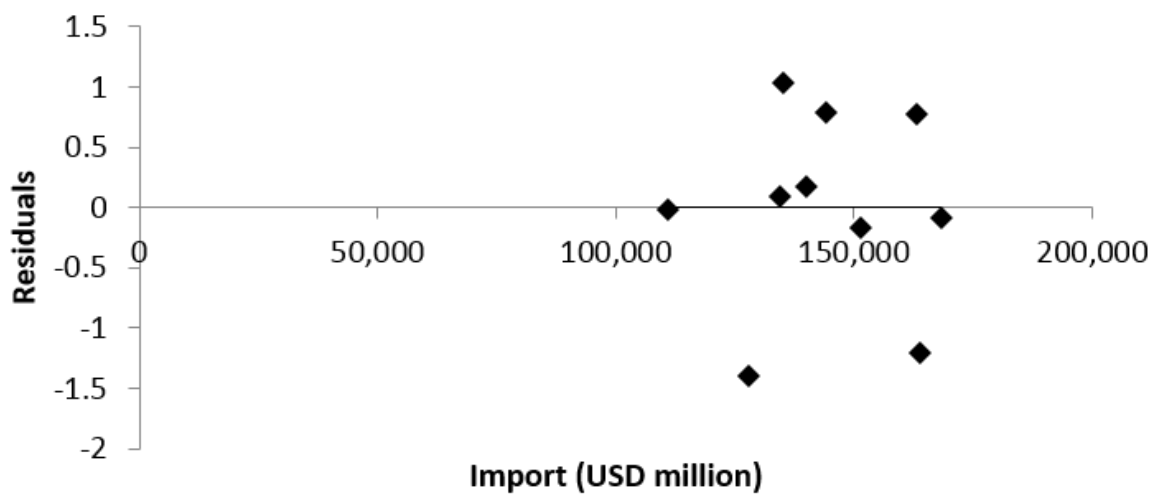

Figure 3: Residual Plot for Export Rate

In figure 3, residual plot for import rate in Saudi Arabia shows that the data points are clustered around the range of USD 150,000 million for influencing the growth of automotive industry creating better employment opportunity to strengthen economic condition. 


\section{Normal Probability Plot}

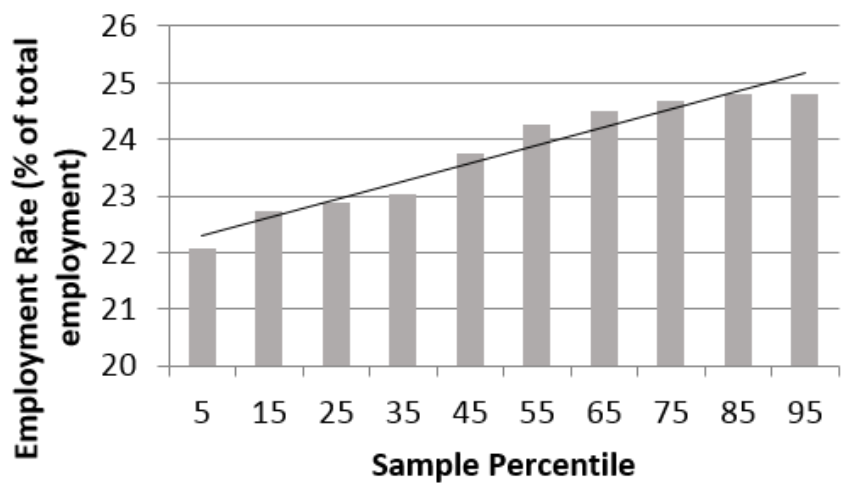

Series1 Linear (Series1)

Figure 4: Normal Probability Plot

Subsequent of the figure 4, the normal probability plot helps to project the distribution of obtained data set and here the diagonal line shows that the data distribution is normal. This is also evident that the increasing employment rate in Saudi Arabia up to $24.79 \%$ in 2020 signifies the growth potential of this sector for utilising the labour force and boosting economic growth (Data.worldbank.org, 2021a).

Since automotive industry is likely to generate a significant number of sales through creating better job opportunity and supporting the economic growth, it can improve the infrastructure for enhancing economic growth. In case of Saudi Arabia, the automotive sector concentrating on improving the automotive infrastructure through supporting the manufacturing of electric vehicles can be essential to create more job opportunities. In this context, approaches of SEEC (Saudi Arabia Energy Efficiency Centre) to implement manufacturing and production standards followed in US can be advantageous for the country to attract foreign investments. This, as a result, can also help to enhance the import and export rates in terms of enhancing trade activities for improving the economic condition. As mentioned by Yamada (2018), investing in the economic growth of a country through industrialisation can boost the overall financial and labour market. It can also create better employment opportunities through establishing factories and manufacturing hubs.

Apart from this, increased trade balance also signifies the increasing value of national currency for supporting the business growth (Algaeed, 2021). Now, following the case of auto-mobile manufacturing industry in Saudi Arabia, changing rates of trade balance indicates towards the existing volatility of the economic and trade condition affecting national economy. Here, trade volume has been decreased from US\$ 510,186 million in 2014 up to US\$ 266 million in 2020 (Trendeconomy.com, 2021). This indicates that increasing vulnerabilities in trade trans-actions affecting import and export rates in Saudi Arabia is likely to hold significant im-pact on industrial growth of this company, especially in case of automobile manufacturing industry. In addition, constant changes in unemployment rates in Saudi Arabia can be influential to boost the economic growth 
through controlling the labor market. Here, unemployment rate has been fluctuated from $5.52 \%$ in 2012 to $5.86 \%$ in 2020 (Data.worldbank.org, 2021b). Therefore, it can be interpreted that although increasing vulnerability and liquidity issues has affected the industrial growth by influencing automobile industry, it can affect the employment rate. Furthermore, changes in the import and export rates in the company can help to support the job creation for improving employment market.

\subsection{Discussion}

This section of the paper has emphasized on collecting and interpreting relevant quantitative data on import and export rates of automobile industry to influence the employment market. Comprehensive assessment of this segment helps to identify that change in the import and export rates can hold significant impact on boosting the overall trade balance and trade volume. This, as a result, can notify the flow of foreign investments to improve the economic condition of a country. In addition, it has also been crucial to emphasize on directing trade volume for making more investment in supporting industrial growth. Furthermore, growing vulnerabilities in economy and liquidity issues can affect the job market for improving the employment market. Besides, this can be effective to contribute to the economic growth of chosen country Saudi Arabia. Apart from this, based on the statistical data obtained from the correlation and multiple regression analysis, the study has been carried out in the next section through highlighting the outputs of hypothesis testing. In this context, results of the hypothesis testing have also been discussed in the next segment for recommending effective solutions to utilize the growth of automobile industry in creating employment opportunities.

\section{Conclusions}

\subsection{Answers to the hypothesis}

The study aims to find if the increasing rate of export has any notable impact on the overall trade volume and if it can create more employment opportunities. Dependent factors such as the overall import rates are also considered here. Along with that, scenarios related to increasing the controlling trade volume towards better job opportunities is mentioned also as a part of the hypothesis.

The results are as per the following:

1. It can be stated from the data gathered from overall research that hypothesis 1 is accepted. Increasing the overall export rate can boost the overall trade volume. This will also be viable for creating more job opportunities in the region.

2. It can be stated from the data gathered from overall research that hypothesis 2 is poorly met. The increasing import rate can impact controlling trade volume that will create better employment opportunities. However, there are other factors present in this scenario, which is not covered in the research.

3. It can be stated from the overall research data that hypothesis 3 is not accepted. Evaluating the total trade balance will not result in more incoming employment opportunities for the locals.

4. It can be stated from the overall research data that hypothesis 4 is accepted. The automobile sector in Saudi Arabia holds a significant amount of impact that can boost 
trade volumes along with increasing employment rates that can reduce the rate of unemployment in the region.

\subsection{Future Recommendation}

The Saudi Arabia automotive cluster is showing a lot of prospects for business growth in the near future. There are certain areas of improvement in this sector that can be implemented for better operational outcome. According to the statement of Urciuoli and Hintsa (2017), existing gaps in the sector can be analyzed so that recommendations can be provided for betterment. It has been found from research that the existing regulations or restrictions of Saudi Arabia trade policies can be a problem. It is essential to implement regulations in such a way that they do not interfere with foreign investments. The government should also en-courage more amount of foreign investment in the concerned sector.

As a part of the overall strategic development plan, the key performance indicators need to be identified and emphasized on. The import rate can also be reduced so that more entries are observed in the market. The government should also increase the export rates and by doing so, more revenue can be generated from this industry. To create and sustain a steady rate of employment, the locals should be included as an element of the development plan so that they can be efficiently employed towards the concerned companies in that segment.

\section{Acknowledgments}

The authors are grateful to the anonymous referees of the journal for their extremely useful suggestions to improve the quality of the article. Usual disclaimers apply.

\section{References}

Algaeed, A.H., 2021. Capital market development and economic growth: an ARDL approach for Saudi Arabia, 1985-2018. Journal of Business Economics and Management, 22(2), pp.388-409.

Ali, M.H., Uddin, M.A., Chowdhury, M.A.F. and Masih, M., 2019. Cross-country evidence of Islamic portfolio diversification: are there opportunities in Saudi Arabia?. Managerial Finance.

Azam, A., 2017. Effect of Economic Crisis on Saudi Arabian Consumers' Behavior Towards Luxury Goods. International Journal of Sustainable Economies Management (IJSEM), 6(4), pp.1-12.

Bell, E., Bryman, A. and Harley, B., 2018. Business research methods. Oxford: Oxford university press.

Belloumi, M. and Alshehry, A., 2020. The Impact of International Trade on Sustainable Development in Saudi Arabia. Sus-tainability, 12(13), p.5421.

Brenner, W. and Herrmann, A., 2018. An overview of technology, benefits and impact of automated and autonomous driving on the automotive industry. Digital marketplaces unleashed, pp.427-442.

Brown, R., 2019. Shifting sands of time: The changing nature of Saudi Arabia's automotive industry. Automotive Logistics. Available at: https://www.automotivelogistics.media/policy-andregulation/shifting-sands-of-time-the-changing-nature-of-saudi-arabias-automotiveindustry/38939.article [Accessed on: 20 February 2021]

Ceicdata.com, 2019. Saudi Arabia Trade Balance. [Online] Available at: https://www.ceicdata.com/en/indicator/saudi-arabia/trade-balance [Accessed on 16th February 2021]

Data.worldbank.org, 2021a. Employment in industry (\% of total employment) (modeled ILO estimate) - Saudi Arabia. [Online] Available at: https://data.worldbank.org/indicator/SL.IND.EMPL.ZS?end=2020 \&locations $=$ SA\&start $=2011$ [Accessed on 19th February 2021] 
Data.worldbank.org, 2021b. Unemployment, total (\% of total labor force) (modeled ILO estimate) - Saudi Arabia. [Online] Available at: https://data.worldbank.org/indicator/SL.UEM.TOTL.ZS?end $=2020 \&$ locations $=$ SA\&start $=2011$ [Accessed on 17th February 2021]

Esmail, H., 2018. Economic growth of Saudi Arabia between present and future according to 2030 vision. Asian Social Science, 14(12), p.192.

Fraga-Lamas, P. and Fernández-Caramés, T.M., 2019. A review on blockchain technologies for an advanced and cyber-resilient automotive industry. IEEE Access, 7, pp.17578-17598.

Iansiti, M. and Lakhani, K.R., 2017. Managing our hub economy. HBR'S 10 MUST, p.117.

Jadoon, G., Ud Din, I., Almogren, A. and Almajed, H., 2020. Smart and agile manufacturing framework, a case study for au-tomotive industry. Energies, 13(21), p.5766.

Jawadi, F., Jawadi, N. and Cheffou, A.I., 2018. Toward a new deal for Saudi Arabia: oil or Islamic stock market investment? Applied Economics, 50(59), pp.6355-6363.

Mahmood, H. and Alkhateeb, T.T.Y., 2017. Trade and environment nexus in Saudi Arabia: An environmental Kuznets curve hypothesis. International Journal of Energy Economics and Policy, 7(5), pp.291-295.

Mirza, A. 2021. Market share of new car sales in Saudi Arabia in 2020, by select brand. Available at: https://www.statista.com/statistics/673095/saudi-arabia-car-sales-market-share-by-brand/ [Accessed on: 20 February 2021]

Park, Y.E., 2018. The endless challenges of KIA motors for globalization: A case study on kia in Saudi Arabia. The Journal of Industrial Distribution \& Business, 9(9), pp.45-52.

Saudiembassy.net, 2021. About Saudi Arabia. Available at: https://www.saudiembassy.net/economy-globaltrade [Accessed on 20 February 2021]

Shafie, S.H.M. and Mahmud, M., 2020. Urban Air Pollutant from Motor Vehicle Emissions in Kuala Lumpur, Malaysia. Aerosol and Air Quality Research, 20.

Shams, S.R. and Thrassou, A., 2019. Theorization and industry-based research project development: Bridging the industry-academia research gap. Industry and Higher Education, 33(2), pp.79-82.

Specia, M, 2019. Saudi Arabia Granted Women the Right to Drive. A Year on, It's Still Complicated. The New York Times. Available at: https://www.nytimes.com/2019/06/24/world/middleeast/saudidriving-ban-anniversary.html\#: :text=Saudi\%20Arabia\%20gran-

ted $\% 20$ women $\% 20$ the $\% 20$ right $\% 20$ to $\% 20$ drive $\% 20$ one $\% 20$ year,long $\% 20$ lived $\% 20$ under $\% 20$ repr essive $\% 20$ laws.\&text $=$ Here's $\% 20$ what $\% 20$ to $\% 20$ know $\% 20$ a,on $\% 20$ female $\% 20$ drivers $\% 20$ was $\% 2$ 0lifted. [Accessed on 20 February 2021]

Tausif, M.R. and Haque, M.I., 2019. Changing Market Scenario of Automobile sector in Saudi Arabia. International Journal of Innovative Technology and Exploring Engineering, 8(9), pp.1-8.

Trade.gov, 2019. Saudi Arabia - Country Commercial Guide. Available at: https://www.trade.gov/knowledgeproduct/saudi-arabia-automotive-market [Accessed on 20 February 2021]

Trendeconomy.com, 2021. Saudi Arabia | Imports and Exports | World | ALL COMMODITIES | Netweight (kg); Quantity and Value (US\$) | 2008 - 2019. [Online] Available at: https://trendeconomy.com/data/h2/SaudiArabia/TOTAL [Accessed on 18th February 2021]

Urciuoli, L. and Hintsa, J., 2017. Adapting supply chain management strategies to security-an analysis of existing gaps and recommendations for improvement. International Journal of Logistics Research and Applications, 20(3), pp.276-295.

Yamada, M., 2018. Can Saudi Arabia Move beyond? The Middle East Journal, 72(4), pp.587-609. 